\title{
Effect of inoculants and storage temperature on the microbial, chemical and mycotoxin composition of corn silage
}

\author{
Musen Wang ${ }^{1}$, Shengyang $X u^{1}$, Tianzheng Wang ${ }^{1}$, Tingting Jia ${ }^{1}$, Zhenzhen $X u^{2}$, Xue Wang ${ }^{2}$, and Zhu Yu ${ }^{1 \text {,* }}$
}

* Corresponding Author: Zhu Yu Tel: +86-010-6273-3414, Fax: +86-010-6273-2799

E-mail: yuzhu33150@sina.com

${ }^{1}$ Department of Grassland Science, China Agricultural University, Beijing 100193, China

2 Institute of Quality Standards and Testing Technology for Agricultural Products, Chinese Academy of Agricultural Science, Beijing 100081, China

ORCID

Zhu Yu

https://orcid.org/0000-0003-3271-1272

Submitted Nov 3, 2017; Revised Dec 18, 2017; Accepted Jan 26, 2018
Objective: To evaluate the effect of lactic acid bacteria and storage temperature on the microbial, chemical and mycotoxin composition of corn silage.

Methods: Corn was harvested at 32.8\% dry matter, and chopped to 1 to $2 \mathrm{~cm}$. The chopped material was subjected to three treatments: i) control (distilled water); ii) $1 \times 10^{6}$ colony forming units (cfu)/g of Lactobacillus plantarum; iii) $1 \times 10^{6} \mathrm{cfu} / \mathrm{g}$ of Pediococcus pentosaceus. Treatments in triplicate were ensiled for $55 \mathrm{~d}$ at $20^{\circ} \mathrm{C}, 28^{\circ} \mathrm{C}$, and $37^{\circ} \mathrm{C}$ in 1 - $\mathrm{L}$ polythene jars following packing to a density of approximately $800 \mathrm{~kg} / \mathrm{m}^{3}$ of fresh matter, respectively. At silo opening, microbial populations, fermentation characteristics, nutritive value and mycotoxins of corn silage were determined.

Results: L. plantarum significantly increased yeast number, water soluble carbohydrates, nitrate and deoxynivalenol content, and significantly decreased the ammonia $\mathrm{N}$ value in corn silage compared with the control $(\mathrm{p}<0.05)$. P. pentosaceus significantly increased lactic acid bacteria and yeast number and content of deoxynivalenol, nivalenol, T-2 toxin and zearalenone, while decreasing mold population and content of nitrate and 3-acetyl-deoxynivalneol in corn silage when stored at $20^{\circ} \mathrm{C}$ compared to the control $(\mathrm{p}<0.05)$. Storage temperature had a significant effect on deoxynivalenol, nivalenol, ochratoxin $\mathrm{A}$, and zearalenone level in corn silage $(\mathrm{p}<0.05)$.

Conclusion: Lactobacillus plantarum and Pediococcus pentosaceus did not decrease the contents of mycotoxins or nitrate in corn silage stored at three temperatures.

Keywords: Lactobacillus plantarum; Pediococcus pentosaceus; Corn Silage; Nutritive Value; Mycotoxin

\section{INTRODUCTION}

Corn is widely utilized as a ensiling material throughout the world, and corn plants in the field can be contaminated with fungi and mycotoxin formation may occur under unfavorable conditions, such as high temperature and drought stress. These fungi and mycotoxins produced can survive the ensiling process and cause animal health problems. Mycotoxins are low molecular weight secondary metabolites formed mainly by Aspergillus, Penicillium, and Fusarium species [1]. The most common mycotoxins in livestock feeds are aflatoxin $B_{1}$ $\left(\mathrm{AFB}_{1}\right)$, ochratoxin $\mathrm{A}(\mathrm{OTA})$, zearalenone (ZEA) and trichothecenes. Mycotoxin contamination not only results in reduced animal feed intake, reproduction and feed conversion efficacy [2], but also may cause carcinogenesis, teratogenesis and immune system suppression as a result of chronic toxicity even at low levels [3,4]. Moreover, the presence of multiple mycotoxins is of particular concern due to potential synergistic effects on livestock exposed to moldy silage [3]. Another issue is that mycotoxins show higher resistance than mycelia to feedstuff processing and storage [5]. Thus, it is important to identify the methods for degrading or transforming mycotoxins in silage. Physical and chemical approaches, such 
as an addition of ammonia and adsorbents $[4,6]$, may be dangerous to applicators. In addition, some adsorbents even bind minerals and vitamins as well as mycotoxins, reducing feed quality [7].

A few studies have indicated that mycotoxins can be degraded or transformed by some microbes. Rumen microflora can degrade and inactivate mycotoxins [8], and intestinal microbes were shown to convert ZEA to $\alpha$-zearalenol and an unknown metabolite [9]. Some reduction of mycotoxins produced in the field was attributed to lactic acid bacteria (LAB) [10]; an in vitro study reported that binding of (deoxynivalenol) DON and ZEA is the major mode of action for LAB [11]. Microbial activity during silage fermentation caused the breakdown of mycotoxin ZEA [12], and Lactobacilli and Pediococcus species were reported to be able to transform some mycotoxins [13]. Mold normally grows at $10^{\circ} \mathrm{C}$ to $40^{\circ} \mathrm{C}$, and Aspergillus and Penicillium species can grow at higher temperatures than Fusarium species [14]. However, mold growth under the optimum temperature range is not necessary for mycotoxins production. A comparison of the optimum temperature for mycotoxins formation by Aspergillus, Penicillium and Fusarium species [15], defined the temperature range of mycotoxins production for A. flavus $\left(\mathrm{AFB}_{1}\right)$, P. verrucosum (OTA) and Fusarium species (toxin T-2, DON, nivalenol [NIV] and ZEA) to be $12^{\circ} \mathrm{C}$ to $40^{\circ} \mathrm{C}, 4^{\circ} \mathrm{C}$ to $20^{\circ} \mathrm{C}$, and $24^{\circ} \mathrm{C}$ to $26^{\circ} \mathrm{C}$, respectively. To date, few studies have evaluated the effect of LAB on the stability of mycotoxins in corn silage stored at different temperatures.

Thus, the objective of this study was to evaluate the effect of inoculants and storage temperature on the microbial populations, fermentation characteristics, nutritive value and mycotoxins of corn silage.

\section{MATERIALS AND METHODS}

\section{Silage preparation}

Corn was grown at the Zhuozhou experimental farm of China Agricultural University (Hebei Province: N 39 $35^{\prime} 25^{\prime \prime}-39^{\circ} 36^{\prime} 05^{\prime \prime}$, E $115^{\circ} 42^{\prime} 12^{\prime \prime}-116^{\circ} 14^{\prime} 35^{\prime \prime}$, elevation 22 to $65 \mathrm{~m}$, annual mean temperature $11.6^{\circ} \mathrm{C}$, and annual average precipitation 554 $\mathrm{mm}$ ). Organic matter, hydrolyzable $\mathrm{N}$, available $\mathrm{P}$ and rapidly available $\mathrm{K}$ content in the field was $16,000,89,26.2$, and 83 $\mathrm{mg} / \mathrm{kg}$, respectively. The cultivar 'Xianyu045' was established on 8 June 2016, with about 64,000 plants/hectare. A compound fertilizer $\left(\mathrm{N}+\mathrm{P}_{2} \mathrm{O}_{5}+\mathrm{K}_{2} \mathrm{O} \geq 45 \%, 800 \mathrm{~kg} /\right.$ hectare $)$ was applied preplant, and urea (320 kg/hectare) was supplemented at the fourteenth-leaf stage on 18th July 2016. A $3 \times 3$ factorial arrangement was used in a completely randomized design. Corn was harvested at $32.8 \%$ dry matter (DM), and chopped to 1 to $2 \mathrm{~cm}$ with a forage chopper on 8th September 2016 . The chopped forage was subjected to three treatments: i) control (distilled water, CK); ii) $1 \times 10^{6}$ colony forming units (cfu)/g of Lactobacillus plantarum KR107070 (LP), isolated from Chinese wild rye (Leymus chinensis) [16]; iii) $1 \times 10^{6} \mathrm{cfu} / \mathrm{g}$ of Pediococcus pentosaceus 17604 (PP), isolated from alfalfa silage. Treated forage in triplicate was ensiled in 1-L polythene jars (Hewanglan Paper and Plastic Products Factory, Beijing, China) following packing with a cylindrical rod and an axe to a density of about $800 \mathrm{~kg}$ of fresh weight $/ \mathrm{m}^{3}$. Laboratory silos were stored at $20^{\circ} \mathrm{C}, 28^{\circ} \mathrm{C}$, and $37^{\circ} \mathrm{C}$ for $55 \mathrm{~d}$, respectively, with 27 silos in all.

\section{Chemical and microbial analyses}

At silo opening, corn silage mass was mixed manually prior to sampling. A subsample of $20 \mathrm{~g}$ was weighed into a blender jar, diluted with $180 \mathrm{~mL}$ of distilled water, and homogenized with a juicer for $2 \mathrm{~min}$. Extracted solution was filtered through four layers of cheesecloth and one layer of qualitative filter paper, and analyzed for $\mathrm{pH}$ value using an electrode (PHS-3C, INESA, Shanghai, China). Then, $2 \mathrm{~mL}$ of filtrate was centrifuged at $10,000 \mathrm{~g}$ at $4^{\circ} \mathrm{C}$ for $5 \mathrm{~min}$ and reserved for fermentation acids and ammonia $\mathrm{N}\left(\mathrm{NH}_{3}-\mathrm{N}\right)$ analysis. Lactic, acetic, propionic, and butyric acids were determined by high performance liquid chromatograph (HPLC, SHIMADZU-10A, Kyoto, Japan). The HPLC system consisted of a Shimadzu system controller (SCL-10A), and a Shodex Rspak KC-811 S-DVB gel column $(300 \mathrm{~mm} \times 8 \mathrm{~mm})$ with a column temperature of $50^{\circ} \mathrm{C}$. The mobile phase was $3 \mathrm{mmol} \mathrm{HClO}_{4}$ running at $1 \mathrm{~mL} / \mathrm{min}$, and the injection volume was $5 \mu \mathrm{L}$. A UV detector (SPD-10A) was used for detection at $210 \mathrm{~nm}$. $\mathrm{NH}_{3}-\mathrm{N}$ was determined by the phenol method.

A second subsample of $200 \mathrm{~g}$ from the ensiled forage or silage was dried in a forced-draft oven at $65^{\circ} \mathrm{C}$ for at least 48 $\mathrm{h}$ to determine DM. Neutral detergent fiber and acid detergent fiber were determined according to Van Soest et al [17]. Water soluble carbohydrates (WSC) were determined using the anthrone method. Nitrogen was analyzed according to Kjeldahl method. Crude protein was calculated by multiplying 6.25 with $\mathrm{N}$ content. Ether extract (EE) was determined by petroleum ether extraction using filter bag technology. A XT4 filter bag was filled with $1 \mathrm{~g}$ of sample, sealed with a capper, and extracted in a X15I FAT EXTRACTOR (ANKOM Technology Corp., Macedon, NY, USA) with petroleum ether (analytical reagent grade, $30^{\circ} \mathrm{C}$ to $60^{\circ} \mathrm{C}$ ) for $1 \mathrm{~h}$. Petroleum ether was purchased from Sinopharm Chemical Reagent Co., Ltd (Beijing, China). Nitrate was determined by the salicylic acid method.

The third subsample of $20 \mathrm{~g}$ from silage was put into a sterile triangular flask, suspended in $180 \mathrm{~mL}$ of sterile solution ( $1 \mathrm{~g}$ of peptone and $9 \mathrm{~g}$ of sodium chloride per liter), and homogenized in a laboratory oscillator at a low speed for 30 $\mathrm{min}$. A series of dilute solutions were prepared for microbial count. The LAB were measured on MRS agar by incubating plates at $37^{\circ} \mathrm{C}$ for $2 \mathrm{~d}$ under anaerobic conditions. Coliform 
bacteria $(\mathrm{CB})$ were estimated following growth on violet red bile agar incubated at $37^{\circ} \mathrm{C}$ for $3 \mathrm{~d}$. Yeast and mold were determined on rose bengal medium after incubation at $28^{\circ} \mathrm{C}$ for $3 \mathrm{~d}$ and 5 to $7 \mathrm{~d}$, respectively, with yeast and mold numbers counted separately according to their macromorphological characteristics. Bacteria and fungi were counted on the plates that yield 30 to $400 \mathrm{cfu}$ and 1 to $100 \mathrm{cfu}$, respectively. All media used were obtained from Beijing Aoboxing Biotech Co., Ltd (Beijing, China).

\section{Mycotoxins determination}

Reagents and solutions: Mycotoxin standard solution NIV $(100 \mu \mathrm{g} / \mathrm{mL}), \mathrm{DON}(100 \mu \mathrm{g} / \mathrm{mL}), 3$-acetyl-deoxynivalneol (3-ADON, $100 \mu \mathrm{g} / \mathrm{mL}), \mathrm{AFB}_{1}(2 \mu \mathrm{g} / \mathrm{mL}), \mathrm{HT}-2(100 \mu \mathrm{g} / \mathrm{mL})$, T-2 $(100 \mu \mathrm{g} / \mathrm{mL})$, OTA $(10 \mu \mathrm{g} / \mathrm{mL})$, and ZEA $(10 \mu \mathrm{g} / \mathrm{mL})$ was obtained from Romer Lab (Romer Labs Inc., Newark, NJ, USA). Diluted solutions were prepared immediately before use by diluting the standard solutions with methanol. A stock solution was composed of eight mycotoxins described above, and prepared by combining suitable aliquots of each individual standard dilution to make each mycotoxin $1 \mu \mathrm{g} / \mathrm{mL}$. A working solution of mycotoxin mixtures was made using a stock solution of the following concentrations: $0.5,1,5,10,20,50$, and $100 \mathrm{ng} / \mathrm{mL}$. Liquid chromatograph-mass spectrometry grade methanol was purchased from J\&K Scientific Ltd (Beijing, China). Acetic acid (guaranteed reagent grade) was obtained from Sigma-Aldrich (Shanghai, China). All reagents (analytical reagent grade) were supplied by Yanxiwan Chemical Reagent Company (Beijing, China), and 15 and $50 \mathrm{~mL}$ polyethylene centrifuge tubes used were purchased from Corning Inc. (Corning, NY, USA).

Extraction procedure and clean-up: For silage extracting, the QuEChERS extraction method was used $[18,19]$, where $5 \mathrm{~g}$ of DM silage was weighed into a $50 \mathrm{~mL}$ centrifuge tube, soaked in $10 \mathrm{~mL}$ of $2 \%$ formic acid for $30 \mathrm{~min}$, and oscillated on a rotary shaker for $30 \mathrm{~min}$ at $240 \mathrm{rpm}$ after an addition of $10 \mathrm{~mL}$ of acetonitrile. Subsequently, $4 \mathrm{~g}$ of $\mathrm{MgSO}_{4}$ and $1 \mathrm{~g}$ of $\mathrm{NaCl}$ were added, and the tube was capped immediately (a brief hand shaking was done immediately after an addition of salts to prevent agglomeration). The slurry was immediately oscillated for $30 \mathrm{~s}$ with a vortex mixer and centrifuged at $10,000 \mathrm{~g}$ for $5 \mathrm{~min}$ at $4^{\circ} \mathrm{C}$, with an aim to induce phase separation and mycotoxins partitioning. Removal of residual water and cleanup were performed simultaneously by using a rapid procedure called dispersive solid-phase extraction (dispersive-SPE), where $2 \mathrm{~mL}$ of acetonitrile extract was mixed with $300 \mathrm{mg}$ of $\mathrm{MgSO}_{4}$ and $100 \mathrm{mg}$ of $\mathrm{C}_{18}$ endcapped silica sorbent (Agilent Technologies, Santa Clara, CA, USA) in a $15 \mathrm{~mL}$ centrifuge tube, and centrifuged at 10,000 $\mathrm{g}$ for $1 \mathrm{~min}$ at $4^{\circ} \mathrm{C}$. A portion of the final solution $(1 \mathrm{~mL})$ was filtered to a sample bottle (Agilent Technologies, USA) by a $0.22 \mu \mathrm{m}$ syringe filter, and stored at $-20^{\circ} \mathrm{C}$ until further analysis.
Instrumental conditions: Instrumental conditions were set according to the Agilent Mass Spectrometry (MS) Technology Products Solutions solution package (mycotoxin, 1290-6470 Parameters, Agilent Technologies, USA). An Agilent infinity 1290 ultra-high performance liquid chromatography (UHPLC) system (Agilent Technologies, USA) was utilized throughout the study. This instrument consisted of a UHPLC pump with a built-in micro-degasser, an infinity autosampler with backflush function, and a temperature control compartment. Chromatographic separation was achieved using an Agilent Eclipse Plus column ( $1.8 \mu \mathrm{m}, 100 \mathrm{~mm} \times 2.1 \mathrm{~mm}$, Agilent Technologies, USA) at a flow rate of $300 \mu \mathrm{L} / \mathrm{min}$, with a mobile phase consisting of solvent $\mathrm{A}$ and solvent $\mathrm{B}$, where solvent $\mathrm{A}$ was water solution containing $1 \%$ acetic acid and $5 \mathrm{mM}$ ammonium acetate, and solvent $\mathrm{B}$ was methanol. The chromatogram of 8 mycotoxins mixed standard solution and gradient elution program are shown in Figure 1 and Table 1, respectively. The injection volume of each sample was $2 \mu \mathrm{L}$ and column temperature was $40^{\circ} \mathrm{C}$.

Analytes were detected using an Agilent 6470 triple quadrupole MS equipped with a Jet Stream electrospray ionization probe. MS was operated in dynamic multi-reaction monitor by monitoring two transitions (one quantifier and the other qualifier) for each analyte, with individual dwell time. MS parameters were as follows: gas temperature $300^{\circ} \mathrm{C}$; sheath gas temperature $350^{\circ} \mathrm{C}$; gas flow $7 \mathrm{~L} / \mathrm{min}$, sheath gas flow $11 \mathrm{~L} / \mathrm{min}$, and capillary 3,500 V, positive. The acquisition was performed in positive polarity, and the optimized MS conditions are outlined in Table 2 . Linearity was established by injecting increasing concentrations (triplicates) of working solution $(0.5,1,5,10,20,50$, and $100 \mathrm{ng} / \mathrm{mL})$. Standard curves were linear in the range studied, showing correlation coefficients of $>0.999$. Quantification and detection limits were determined by spiked samples based on signal-to-noise ratios of 10:1 for quantification and 3:1 for detection limit.

\section{Statistical analysis}

All microbial counts (LAB, yeast, mold, and CB) were transformed to $\log 10$ units on fresh weight basis. Data of the fermentation characteristics, microbial populations, nutritive value and mycotoxin content in silage were analyzed by the Factorial Design model of SAS (9.1 version, SAS Institute Cary, NC, USA). The model used for the analysis was: $Y=\mu$ + treatment + storage temperature + treatment $\times$ storage temperature $+\varepsilon$, where $Y=$ observation, $\mu=$ general mean, treatment $=$ effect of $\mathrm{CK}$ or LP or PP, storage temperature $=$ effect of $20^{\circ} \mathrm{C}$ or $28^{\circ} \mathrm{C}$ or $37^{\circ} \mathrm{C}$, treatment $\times$ storage temperature $=$ interaction between treatment and storage temperature, $\varepsilon$ $=$ residual error. Bon grouping contrasts were utilized to compare means among four levels of one factor with the other factor immobilized. The significant difference was declared at $\mathrm{p}<0.05$. 


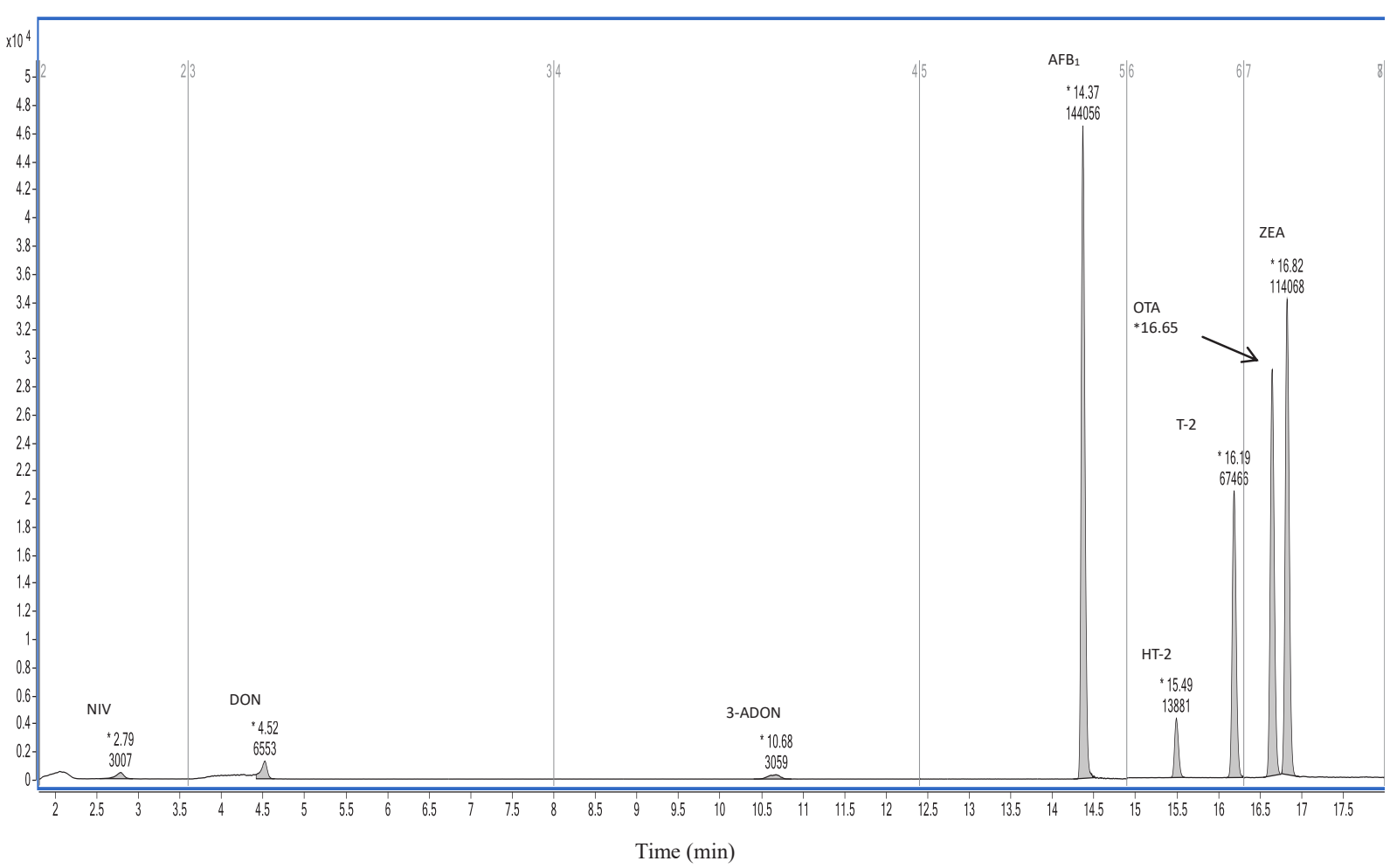

Figure 1. The chromatogram of nivalenol, deoxynivalenol, 3-acetyl-deoxynivalneol, aflatoxin $B_{1}, H T-2$ toxin, T-2 toxin, ochratoxin A, and zearalenone at $100 \mathrm{ng} / \mathrm{mL}$.

Table 1. Elution condition for the mobile phase

\begin{tabular}{lcc}
\hline Time (min) & Solvent A (\%) & Solvent B (\%) \\
\hline 0 & 90 & 10 \\
2 & 90 & 10 \\
3 & 80 & 20 \\
7 & 76 & 24 \\
10.5 & 70 & 30 \\
13.5 & 40 & 60 \\
15 & 30 & 70 \\
18 & 25 & 75 \\
18.1 & 5 & 95 \\
21.9 & 5 & 95 \\
22 & 90 & 10 \\
25 & 90 & 10 \\
\hline
\end{tabular}

\section{RESULTS}

Chemical, microbial and mycotoxin composition of corn Chemical and microbial composition and mycotoxin content of ensiling plant are presented in Table 3 and 4, respectively. Nitrate, DON, and ZEA content of corn was $383 \mathrm{mg} / \mathrm{kg}, 163$ and $30.6 \mathrm{ng} / \mathrm{g}$ accordingly.

Microbial and chemical composition of corn silage Table 5 shows the microbial counts and fermentation characteristics of corn silage treated with inoculants and storage temperature. LAB count in PP-treated silage silage stored at $20^{\circ} \mathrm{C}$ was higher than CK and LP $(\mathrm{p}<0.05)$, and their count

Table 2. Chromatographic and mass spectrometric parameters for the detection of mycotoxins

\begin{tabular}{|c|c|c|c|c|c|c|c|c|}
\hline Analyte & Precursor ion & $\begin{array}{c}\text { Product ion } \\
\text { (quantification) }\end{array}$ & $\begin{array}{l}\text { Product ion } \\
\text { (qualifier) }\end{array}$ & $\begin{array}{l}\text { Dwell time } \\
\quad(\mathrm{ms})\end{array}$ & $\begin{array}{l}\text { Collision energy } \\
\text { (V) }\end{array}$ & $\begin{array}{l}\text { Retention time } \\
\text { (min) }\end{array}$ & $\begin{array}{l}\text { Limit of } \\
\text { detection } \\
\text { (ng/g) }\end{array}$ & $\begin{array}{l}\text { Limit of } \\
\text { quantification } \\
\text { (ng/g) }\end{array}$ \\
\hline NIV & 371 & 281 & 59.1 & 100 & 10 & 2.79 & 1 & 5 \\
\hline DON & 355 & 265 & 59 & 60 & 10 & 4.52 & 1 & 5 \\
\hline 3-ADON & 339 & 231 & 213 & 100 & 10 & 10.6 & 1 & 5 \\
\hline $\mathrm{AFB}_{1}$ & 313 & 285 & 241 & 30 & 22 & 14.3 & 0.5 & 1 \\
\hline HT-2 & 442 & 263 & 215 & 40 & 10 & 15.4 & 1 & 5 \\
\hline $\mathrm{T}-2$ & 484 & 305 & 185 & 40 & 10 & 16.1 & 0.3 & 1 \\
\hline OTA & 404 & 239 & 358 & 20 & 20 & 16.6 & 0.5 & 1 \\
\hline ZEA & 317 & 175 & 130 & 20 & 25 & 16.8 & 0.5 & 1 \\
\hline
\end{tabular}

NIV, nivalenol; DON, deoxynivalenol; 3-ADON, 3-acetyl-deoxynivalneol; AFB $_{1}$, aflatoxin $B_{1}$; HT-2, HT-2 toxin; T-2, T-2 toxin; OTA, ochratoxin A; ZEA, zearalenone. 
Table 3. Chemical and microbial composition of corn material

\begin{tabular}{|c|c|c|c|c|c|c|c|c|c|c|c|}
\hline \multirow{2}{*}{ Item } & DM & NDF & ADF & $\mathrm{CP}$ & WSC & EE & Nitrate & LAB & Yeast & Mold & CB \\
\hline & - & .... & 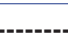 & $\ldots$ & $\ldots$ & -- & $\mathrm{mg} / \mathrm{kg}, \mathrm{D}$ & -----.-. & $--L$ & $/ g$ & \\
\hline
\end{tabular}

DM, dry matter; NDF, neutral detergent fiber; ADF, acid detergent fiber; CP, crude protein; WSC, water soluble carbohydrates; $E E$, ether extract; $L A B$, lactic acid bacteria; $C B$, coliform bacteria; FM, fresh matter; SD, standard deviation.

Data were shown with triplicate.

Table 4. Mycotoxin content of corn material

\begin{tabular}{lcccccccc}
\hline \multirow{2}{*}{ Item } & NIV & DON & 3-ADON & AFB & HT-2 & T-2 & OTA & ZEA \\
\cline { 2 - 7 } & $-\cdots$ & $163.2 \pm 11.18$ & $36.98 \pm 0.47$ & $30.26 \pm 0.77$ & $13.94 \pm 0.82$ & $23.01 \pm 0.14$ & $34.45 \pm 0.27$ & $30.63 \pm 2.64$
\end{tabular}

NIV, nivalenol; DON, deoxynivalenol; 3-ADON, 3-acetyl-deoxynivalneol; AFB, aflatoxin $B_{1} ;$ HT-2, HT-2 toxin; T-2, T-2 toxin; OTA, ochratoxin A; ZEA, zearalenone; SD, standard deviation.

Data were shown with triplicate.

in PP-treated silage silage stored at $28^{\circ} \mathrm{C}$ was higher than LP $(\mathrm{p}<0.05)$, whereas LP-treated silage stored at $37^{\circ} \mathrm{C}$ had a higher count of LAB compared with CK and PP $(\mathrm{p}<0.05)$. Without any treatment, $\mathrm{LAB}$ number in silage conserved at $28^{\circ} \mathrm{C}$ was

Table 5. Microbial populations and fermentation characteristics of corn silage treated with inoculants and storage temperature

\begin{tabular}{|c|c|c|c|c|c|c|c|}
\hline \multirow{2}{*}{ Item } & \multirow{2}{*}{ Treatment } & \multicolumn{3}{|c|}{ Storage temperature $\left({ }^{\circ} \mathrm{C}\right)$} & \multicolumn{3}{|c|}{ p-value } \\
\hline & & 20 & 28 & 37 & $T$ & $S$ & $\mathrm{~T} \times \mathrm{S}$ \\
\hline \multirow[t]{3}{*}{$\angle A B$} & CK & $6.51^{\mathrm{bB}}$ & $7.37^{\mathrm{abA}}$ & $5.33^{\mathrm{bC}}$ & 0.0148 & $<0.0001$ & 0.0023 \\
\hline & $L P$ & $6.26^{b}$ & $6.43^{b}$ & $5.90^{\mathrm{a}}$ & - & - & - \\
\hline & PP & $7.33^{\mathrm{aA}}$ & $7.79^{\mathrm{aA}}$ & $5.26^{\mathrm{bB}}$ & - & - & - \\
\hline \multirow[t]{3}{*}{ Yeast } & CK & $5.35^{\mathrm{cA}}$ & $3.83^{\mathrm{bB}}$ & $3.55^{\mathrm{bB}}$ & $<0.0001$ & $<0.0001$ & 0.3244 \\
\hline & $L P$ & $6.03^{b}$ & $5.52^{\mathrm{a}}$ & $5.00^{\mathrm{a}}$ & - & - & - \\
\hline & PP & $6.34^{\mathrm{aA}}$ & $4.88^{\mathrm{aB}}$ & $4.87^{\mathrm{abB}}$ & - & - & - \\
\hline \multirow[t]{3}{*}{ Mold } & CK & $4.01^{\mathrm{aA}}$ & $3.47^{\mathrm{AB}}$ & $2.80^{B}$ & 0.5366 & 0.0097 & 0.0424 \\
\hline & $L P$ & $3.38^{\mathrm{ab}}$ & 3.36 & 2.80 & - & - & - \\
\hline & PP & $2.80^{\mathrm{bB}}$ & $3.99^{A}$ & $3.00^{B}$ & - & - & - \\
\hline \multirow[t]{3}{*}{$C B$} & CK & $5.74^{\mathrm{A}}$ & $4.42^{B}$ & $4.08^{\mathrm{bB}}$ & 0.2889 & 0.0946 & 0.1605 \\
\hline & $L P$ & 5.13 & 5.34 & $5.03^{\mathrm{ab}}$ & - & - & - \\
\hline & PP & 5.30 & 5.07 & $5.07^{\mathrm{a}}$ & - & - & - \\
\hline \multirow[t]{3}{*}{$\mathrm{pH}$} & CK & $3.71^{\mathrm{bB}}$ & $3.71^{\mathrm{bB}}$ & $3.81^{\mathrm{A}}$ & 0.0005 & $<0.0001$ & 0.2219 \\
\hline & $L P$ & $3.69^{\mathrm{bB}}$ & $3.70^{\mathrm{bB}}$ & $3.83^{\mathrm{A}}$ & - & - & - \\
\hline & PP & $3.80^{\mathrm{aB}}$ & $3.75^{\mathrm{ac}}$ & $3.85^{\mathrm{A}}$ & - & - & - \\
\hline \multirow[t]{3}{*}{$\mathrm{NH}_{3}-\mathrm{N}$} & CK & $2.98^{\mathrm{aB}}$ & $3.98^{\mathrm{aA}}$ & $4.38^{\mathrm{aA}}$ & $<0.0001$ & $<0.0001$ & 0.2937 \\
\hline & $L P$ & $1.90^{\mathrm{bc}}$ & $2.78^{\mathrm{bB}}$ & $3.50^{\mathrm{bA}}$ & - & - & - \\
\hline & PP & $3.01^{\mathrm{aB}}$ & $3.34^{\mathrm{bB}}$ & $4.26^{\mathrm{aA}}$ & - & - & - \\
\hline \multirow[t]{3}{*}{ LA } & CK & 4.91 & 5.16 & 5.23 & 0.1725 & 0.3900 & 0.6227 \\
\hline & $L P$ & 5.53 & 5.76 & 5.54 & - & - & - \\
\hline & PP & 5.19 & 5.57 & 5.56 & - & - & - \\
\hline \multirow[t]{3}{*}{$\mathrm{AA}$} & CK & 1.45 & 1.42 & 1.56 & 0.1202 & 0.4850 & 0.7580 \\
\hline & $L P$ & 1.53 & 1.41 & 1.40 & - & - & - \\
\hline & PP & 1.39 & 1.26 & 1.30 & - & - & - \\
\hline \multirow[t]{3}{*}{ PA } & CK & 0.31 & 0.31 & 0.28 & 0.4567 & 0.0027 & 0.2637 \\
\hline & $L P$ & $0.39^{A}$ & $0.30^{B}$ & $0.28^{B}$ & - & - & - \\
\hline & PP & 0.35 & 0.30 & 0.28 & - & - & - \\
\hline
\end{tabular}

T, treatment effect; $S$, storage temperature effect; $T \times S$, interaction effect between treatment and storage temperature; $L A B$, lactic acid bacteria; $C K$, control; $L P$, Lactobacillus plantarum KR107070; PP, Pediococcus pentosaceus 17604; $\mathrm{CB}$, coliform bacteria; $\mathrm{NH}_{3}-\mathrm{N}$, ammonia nitrogen; $\mathrm{LA}$, lactic acid; $\mathrm{AA}$, acetic acid; $\mathrm{PA}$, propionic acid.

Fermentation indexes are expressed on dry matter (\%) except pH and $\mathrm{NH}_{3}-\mathrm{N}$, and microbial numbers are shown on a $\log _{10}$ unit basis (fresh matter). $\mathrm{NH}_{3}-\mathrm{N}$ is shown on total nitrogen basis (\%).

Means within columns $\left({ }^{(, b, c, d}\right)$ or rows $\left({ }^{A, B, C, D}\right)$ with different letters are significantly different $(p<0.05)$. 
higher in comparison with $20^{\circ} \mathrm{C}$ and $37^{\circ} \mathrm{C}(\mathrm{p}<0.05)$, and their number in silage conserved at $20^{\circ} \mathrm{C}$ was higher compared with $37^{\circ} \mathrm{C}(\mathrm{p}<0.05)$. The addition of PP resulted in a lower population of $\mathrm{LAB}$ in silage conserved at $37^{\circ} \mathrm{C}$ in contrast with $20^{\circ} \mathrm{C}$ and $28^{\circ} \mathrm{C}(\mathrm{p}<0.05)$. Yeast number in any silage decreased as storage temperature increased from $20^{\circ} \mathrm{C}$ to $37^{\circ} \mathrm{C}(\mathrm{p}<0.05)$, regardless of additive effect. Yeast number in LP-treated silage ensiled at any temperature was higher than $\mathrm{CK}(\mathrm{p}<0.05)$, and its number in PP-treated silage ensiled at $20^{\circ} \mathrm{C}$ and $28^{\circ} \mathrm{C}$ was higher than CK $(\mathrm{p}<0.05)$, whereas PP-treated silage ensiled at $20^{\circ} \mathrm{C}$ had a higher count of yeast in comparison with LP $(\mathrm{p}<0.05)$. With the addition of PP or no additive, yeast population in silage ensiled at $20^{\circ} \mathrm{C}$ was higher compared to $28^{\circ} \mathrm{C}$ and $37^{\circ} \mathrm{C}(\mathrm{p}<0.05)$. Mold count in PP-treated silage stored at $20^{\circ} \mathrm{C}$ was lower than CK and LP $(\mathrm{p}<0.05)$. Without any additive, silage stored at $20^{\circ} \mathrm{C}$ had a higher count of mold in contrast with $37^{\circ} \mathrm{C}(\mathrm{p}<0.05)$, whereas the application of PP led to a higher number of mold in silage stored at $28^{\circ} \mathrm{C}$ compared with $20^{\circ} \mathrm{C}$ and $37^{\circ} \mathrm{C}(\mathrm{p}<0.05)$. $\mathrm{CB}$ number in CK-treated silage stored at $37^{\circ} \mathrm{C}$ was lower compared to LP and PP $(\mathrm{p}<$ 0.05 ), and $\mathrm{CK}$-treated silage stored at $20^{\circ} \mathrm{C}$ had a higher number of $\mathrm{CB}$ in comparison with $28^{\circ} \mathrm{C}$ and $37^{\circ} \mathrm{C}(\mathrm{p}<0.05)$.

According to Table 5 , the $\mathrm{pH}$ value in any silage was below 4.0, ranging from 3.69 to 3.85 . The $\mathrm{pH}$ value in PP-treated silage conserved at $20^{\circ} \mathrm{C}$ and $28^{\circ} \mathrm{C}$ was higher than $\mathrm{CK}$ and LP $(\mathrm{p}<0.05)$. With the addition of LP or no additive, silage conserved at $37^{\circ} \mathrm{C}$ had a higher $\mathrm{pH}$ level compared to $20^{\circ} \mathrm{C}$ and $28^{\circ} \mathrm{C}(\mathrm{p}<0.05)$. The application of PP not only resulted in a higher $\mathrm{pH}$ level in silage conserved at $37^{\circ} \mathrm{C}$ in comparison with $20^{\circ} \mathrm{C}$ and $28^{\circ} \mathrm{C}(\mathrm{p}<0.05)$, but also caused a higher value of $\mathrm{pH}$ in silage conserved at $20^{\circ} \mathrm{C}$ compared to $28^{\circ} \mathrm{C}$ $(\mathrm{p}<0.05) . \mathrm{NH}_{3}-\mathrm{N}$ content in any silage increased significantly as conservation temperature increased from $20^{\circ} \mathrm{C}$ to $37^{\circ} \mathrm{C}$ $(\mathrm{p}<0.05)$, irrespective of treatment effect. $\mathrm{NH}_{3}-\mathrm{N}$ content in LP-treated silage stored at any temperature was lower than $\mathrm{CK}(\mathrm{p}<0.05)$, whereas PP-treated silage stored at $28^{\circ} \mathrm{C}$ had a lower level of $\mathrm{NH}_{3}-\mathrm{N}$ in comparison with $\mathrm{CK}(\mathrm{p}<0.05)$. The addition of $\mathrm{LP}$ lowered $\mathrm{NH}_{3}-\mathrm{N}$ level in silage stored at $20^{\circ} \mathrm{C}$ and $37^{\circ} \mathrm{C}$ compared to $\mathrm{PP}(\mathrm{p}<0.05)$. Without any additive, $\mathrm{NH}_{3}-\mathrm{N}$ value in silage ensiled at $28^{\circ} \mathrm{C}$ and $37^{\circ} \mathrm{C}$ was higher compared to $20^{\circ} \mathrm{C}(\mathrm{p}<0.05)$. With the use of $\mathrm{LP} \mathrm{NH}_{3}-\mathrm{N}$ value in silage ensiled at $37^{\circ} \mathrm{C}$ was higher compared to $20^{\circ} \mathrm{C}$ and $28^{\circ} \mathrm{C}(\mathrm{p}<0.05)$, and its content in silage ensiled at $28^{\circ} \mathrm{C}$ was higher than $20^{\circ} \mathrm{C}(\mathrm{p}<0.05)$. The application of PP led to a higher content of $\mathrm{NH}_{3}-\mathrm{N}$ in silage ensiled at $37^{\circ} \mathrm{C}$ compared with $20^{\circ} \mathrm{C}$ and $28^{\circ} \mathrm{C}(\mathrm{p}<0.05)$. PA content in LP-treated silage ensiled at $20^{\circ} \mathrm{C}$ was higher than $28^{\circ} \mathrm{C}$ and $37^{\circ} \mathrm{C}(\mathrm{p}<0.05)$, whereas there were not significant differences on PA content for all the other contrasts $(\mathrm{p}>0.05)$.

Table 6 presents the effect of inoculants on the nutritive value of corn silage stored at three temperatures. DM content in CK-treated silage stored at $37^{\circ} \mathrm{C}$ was lower in comparison with LP and PP $(\mathrm{p}<0.05)$, and there were not significant differences on DM content for all the other contrasts $(\mathrm{p}>0.05)$. $\mathrm{CP}$ level in any silage decreased significantly with storage temperature increasing from $20^{\circ} \mathrm{C}$ to $37^{\circ} \mathrm{C}(\mathrm{p}<0.05)$, irrespective of additive effect. $\mathrm{CP}$ level in CK-treated silage conserved at $28^{\circ} \mathrm{C}$ was lower compared to LP and PP $(\mathrm{p}<0.05)$, whereas its content in LP-treated silage conserved at $37^{\circ} \mathrm{C}$ was higher than $\mathrm{CK}$ and $\mathrm{PP}(\mathrm{p}<0.05)$. With no additive, silage conserved

Table 6. Nutritive value of corn silage treated with inoculants and storage temperature

\begin{tabular}{|c|c|c|c|c|c|c|c|}
\hline \multirow{2}{*}{ Item } & \multirow{2}{*}{ Treatment } & \multicolumn{3}{|c|}{ Storage temperature $\left({ }^{\circ} \mathrm{C}\right)$} & \multicolumn{3}{|c|}{$p$-value } \\
\hline & & 20 & 28 & 37 & $\mathrm{~T}$ & $S$ & $\mathrm{~T} \times \mathrm{S}$ \\
\hline \multirow[t]{3}{*}{$\mathrm{DM}$} & CK & 33.4 & 33.5 & $32.4^{b}$ & 0.0318 & 0.7671 & 0.3377 \\
\hline & $L P$ & 32.9 & 33.3 & $34.2^{\mathrm{a}}$ & - & - & - \\
\hline & PP & 34.2 & 34.7 & $34.3^{\mathrm{a}}$ & - & - & - \\
\hline \multirow[t]{3}{*}{$\mathrm{CP}$} & CK & $7.53^{\mathrm{A}}$ & $7.04^{\mathrm{bB}}$ & $6.99^{\mathrm{bB}}$ & 0.0007 & 0.0002 & 0.2021 \\
\hline & $L P$ & $7.75^{\mathrm{A}}$ & $7.57^{\mathrm{aAB}}$ & $7.36^{\mathrm{aB}}$ & - & - & - \\
\hline & PP & $7.52^{\mathrm{A}}$ & $7.52^{\mathrm{aA}}$ & $7.19^{\mathrm{bB}}$ & - & - & - \\
\hline \multirow[t]{3}{*}{ WSC } & CK & $0.98^{\mathrm{bB}}$ & $0.83^{\mathrm{bc}}$ & $1.19^{c A}$ & $<0.0001$ & $<0.0001$ & 0.0005 \\
\hline & $L P$ & $1.31^{\mathrm{aB}}$ & $1.41^{\mathrm{aB}}$ & $1.65^{\mathrm{aA}}$ & - & - & - \\
\hline & PP & $0.98^{\mathrm{bB}}$ & $0.78^{\mathrm{bc}}$ & $1.43^{\mathrm{bA}}$ & - & - & - \\
\hline \multirow[t]{3}{*}{$\mathrm{EE}$} & CK & 2.12 & 2.26 & 2.22 & 0.6179 & 0.6213 & 0.7625 \\
\hline & LP & 2.17 & 2.10 & 2.11 & - & - & - \\
\hline & PP & 2.09 & 2.29 & 2.26 & - & - & - \\
\hline \multirow[t]{3}{*}{ Nitrate } & CK & $73.9^{b}$ & $71.4^{b}$ & $67.6^{c}$ & $<0.0001$ & 0.2883 & 0.0002 \\
\hline & $L P$ & $91.4^{\mathrm{aA}}$ & $80.5^{\mathrm{aB}}$ & $85.8^{\mathrm{aAB}}$ & - & - & - \\
\hline & PP & $61.1^{c \mathrm{C}}$ & $70.4^{\mathrm{bB}}$ & $78.0^{\mathrm{bA}}$ & - & - & - \\
\hline
\end{tabular}

T, treatment effect; $S$, storage temperature effect; $T \times S$, interaction effect between treatment and storage temperature; DM, dry matter; CK, control; LP, Lactobacillus plantarum KR107070; PP, Pediococcus pentosaceus 17604; CP, crude protein; WSC, water soluble carbohydrates; $E E$, ether extract.

CP, WSC, and CF were expressed on DM\% and nitrate was shown as $\mathrm{mg} / \mathrm{kg}$ (DM).

Means within columns $\left({ }^{a, b, c, d}\right)$ or rows $\left({ }^{A, B, C, D}\right)$ with different letters are significantly different $(p<0.05)$. 
at $20^{\circ} \mathrm{C}$ had a higher content of $\mathrm{CP}$ compared with $28^{\circ} \mathrm{C}$ and $37^{\circ} \mathrm{C}(\mathrm{p}<0.05)$. The application of LP induced a higher value of $\mathrm{CP}$ in silage conserved at $20^{\circ} \mathrm{C}$ in contrast with $37^{\circ} \mathrm{C}$ ( $\mathrm{p}<$ $0.05)$, and $\mathrm{PP}$-treated silage conserved at $37^{\circ} \mathrm{C}$ had a lower value of $\mathrm{CP}$ than 20 and $28^{\circ} \mathrm{C}(\mathrm{p}<0.05)$. WSC content in LPtreated silage ensiled at any temperature was higher compared to $\mathrm{CK}$ and $\mathrm{PP}(\mathrm{p}<0.05)$, whereas its content in PP-treated silage ensiled at $37^{\circ} \mathrm{C}$ was higher than $\mathrm{CK}(\mathrm{p}<0.05)$. With the addition of $\mathrm{PP}$ or no additive, silage ensiled at $37^{\circ} \mathrm{C}$ had a higher level of WSC in comparison with $20^{\circ} \mathrm{C}$ and $28^{\circ} \mathrm{C}(\mathrm{p}<0.05)$, and WSC level in silage ensiled at $20^{\circ} \mathrm{C}$ was higher in contrast with $28^{\circ} \mathrm{C}(\mathrm{p}<0.05)$. The application of LP resulted in a higher value of WSC in silage ensiled at $37^{\circ} \mathrm{C}$ compared to $20^{\circ} \mathrm{C}$ and $28^{\circ} \mathrm{C}(\mathrm{p}<0.05)$, whereas there were no differences on WSC value for all the remaining comparisons ( $\mathrm{p}>0.05$ ). Nitrate content in silage, ranging from 61.1 to $91.4 \mathrm{mg} / \mathrm{kg}$, was lower compared with $383 \mathrm{mg} / \mathrm{kg}$ in corn. At $20^{\circ} \mathrm{C}$, nitrate level in LP-treated silage was higher compared to CK and PP $(\mathrm{p}<0.05)$, and its level in silage treated with $\mathrm{CK}$ was higher than PP $(\mathrm{p}<0.05)$. LP-treated silage stored at $28^{\circ} \mathrm{C}$ had a higher level of nitrate than CK and PP $(p<0.05)$. At $37^{\circ} \mathrm{C}$, nitrate level in silage treated with LP was higher compared to CK and $P P(p<0.05)$, and its level in silage treated with CK was lower in comparison with PP ( $\mathrm{p}<0.05)$. The use of LP led to a higher value of nitrate in silage stored at $20^{\circ} \mathrm{C}$ compared to $28^{\circ} \mathrm{C}(\mathrm{p}<0.05)$, whereas PP-treated silage stored at $37^{\circ} \mathrm{C}$ had a higher value of nitrate than $20^{\circ} \mathrm{C}$ and $28^{\circ} \mathrm{C}(\mathrm{p}<0.05)$, and the application of $\mathrm{PP}$ caused a lower value of nitrate in silage stored at $20^{\circ} \mathrm{C}$ in contrast with $28^{\circ} \mathrm{C}(\mathrm{p}<0.05)$.

\section{Mycotoxin content of corn silage}

Mycotoxin content of corn silage treated with LAB and storage temperature is stated in Table 7. NIV content in PP-treated silage stored at $20^{\circ} \mathrm{C}$ was higher than CK and LP $(\mathrm{p}<0.05)$, whereas its content in PP-treated silage stored at $28^{\circ} \mathrm{C}$ and $37^{\circ} \mathrm{C}$ was lower compared to CK and LP ( $\left.p<0.05\right)$. NIV level in LP-treated silage was higher and lower in comparison with $\mathrm{CK}(\mathrm{p}<0.05)$, at $28^{\circ} \mathrm{C}$ and $37^{\circ} \mathrm{C}$, respectively. Without any additive, NIV value in silage stored at $37^{\circ} \mathrm{C}$ was higher compared to $20^{\circ} \mathrm{C}$ and $28^{\circ} \mathrm{C}(\mathrm{p}<0.05)$, and its value in silage stored at $20^{\circ} \mathrm{C}$ was lower than $28^{\circ} \mathrm{C}(\mathrm{p}<0.05)$. The use of LP resulted in a lower value of NIV in silage stored at $20^{\circ} \mathrm{C}$ in contrast

Table 7. Mycotoxin content of corn silage treated with lactic acid bacteria and storage temperature

\begin{tabular}{|c|c|c|c|c|c|c|c|}
\hline \multirow{2}{*}{ Item } & \multirow{2}{*}{ Treatment } & \multicolumn{3}{|c|}{ Storage temperature $\left({ }^{\circ} \mathrm{C}\right)$} & \multicolumn{3}{|c|}{$p$-value } \\
\hline & & 20 & 28 & 37 & $\mathrm{~T}$ & $S$ & $\mathrm{~T} \times \mathrm{S}$ \\
\hline \multirow[t]{3}{*}{ NIV } & CK & $39.5^{b c}$ & $55.8^{\mathrm{bB}}$ & $137.1^{\mathrm{AA}}$ & $<0.0001$ & $<0.0001$ & $<0.0001$ \\
\hline & $L P$ & $39.1^{\mathrm{bB}}$ & $91.7^{\mathrm{AA}}$ & $87.4^{\mathrm{bA}}$ & - & - & - \\
\hline & PP & $59.6^{\mathrm{aB}}$ & $50.8^{c c}$ & $68.8^{\mathrm{cA}}$ & - & - & - \\
\hline \multirow[t]{3}{*}{ DON } & CK & $56.4^{\mathrm{bA}}$ & $42.5^{\mathrm{bB}}$ & $38.3^{\mathrm{cB}}$ & $<0.0001$ & $<0.0001$ & $<0.0001$ \\
\hline & $L P$ & $76.2^{\mathrm{bc}}$ & $126^{\mathrm{aB}}$ & $179^{\mathrm{aA}}$ & - & - & - \\
\hline & PP & $261^{\mathrm{aA}}$ & $44.1^{b c}$ & $66.2^{\mathrm{bB}}$ & - & - & - \\
\hline \multirow[t]{3}{*}{ 3-ADON } & CK & 38.9 & 36.8 & 37.6 & 0.1870 & 0.1871 & 0.1022 \\
\hline & $L P$ & 37.0 & 37.0 & 37.5 & - & - & - \\
\hline & PP & 37.1 & 37.2 & 37.3 & - & - & - \\
\hline \multirow[t]{3}{*}{$\mathrm{AFB}_{1}$} & CK & 24.5 & 23.9 & 24.2 & 0.3383 & 0.4968 & 0.7451 \\
\hline & $L P$ & 23.6 & 23.6 & 24.3 & - & - & - \\
\hline & PP & 24.0 & 23.4 & 23.7 & - & - & - \\
\hline \multirow[t]{3}{*}{ HT-2 } & CK & 13.4 & 13.3 & 13.6 & 0.7065 & 0.7426 & 0.6698 \\
\hline & $L P$ & 13.4 & 13.8 & 13.0 & - & - & - \\
\hline & PP & 13.8 & 13.6 & 13.5 & - & - & - \\
\hline \multirow[t]{3}{*}{$\mathrm{T}-2$} & CK & 21.9 & 22.3 & 22.2 & 0.7535 & 0.0121 & 0.4168 \\
\hline & $L P$ & 21.9 & 22.7 & 22.0 & - & - & - \\
\hline & PP & 22.2 & 22.4 & 22.1 & - & - & - \\
\hline \multirow[t]{3}{*}{ OTA } & CK & $34.7^{B}$ & $34.9^{\mathrm{bB}}$ & $51.6^{\mathrm{aA}}$ & 0.0001 & $<0.0001$ & $<0.0001$ \\
\hline & $L P$ & $36.2^{B}$ & $36.2^{b B}$ & $39.2^{\mathrm{CA}}$ & - & - & - \\
\hline & PP & $36.5^{c}$ & $40.7^{\mathrm{aB}}$ & $44.1^{\mathrm{bA}}$ & - & - & - \\
\hline \multirow[t]{3}{*}{ ZEA } & CK & $27.5^{b}$ & $30.4^{b}$ & 29.6 & $<0.0001$ & $<0.0001$ & $<0.0001$ \\
\hline & $L P$ & $28.0^{\mathrm{bAB}}$ & $27.4^{\mathrm{bB}}$ & $29.4^{\mathrm{A}}$ & - & - & - \\
\hline & PP & $37.0^{\mathrm{aB}}$ & $62.0^{\mathrm{aA}}$ & $30.6^{\mathrm{B}}$ & - & - & - \\
\hline
\end{tabular}

Mycotoxins were shown on dry matter basis (ng/g).

T, treatment effect; $S$, storage temperature effect; $T \times S$, interaction effect between treatment and storage temperature; NIV, nivalenol; CK, control; $L P$, Lactobacillus plantarum KR107070; PP, Pediococcus pentosaceus 17604; DON, deoxynivalenol; 3-ADON, 3-acetyl-deoxynivalneol; AFB 1 , aflatoxin $B_{1} ; H T-2, H T-2$ toxin; T-2, T-2 toxin; OTA, ochratoxin A; ZEA, zearalenone.

Means within columns $\left({ }^{(, b, c, d}\right)$ or rows $\left({ }^{A, B, C, D}\right)$ with different letters are significantly different $(p<0.05)$. 
with $28^{\circ} \mathrm{C}$ and $37^{\circ} \mathrm{C}(\mathrm{p}<0.05)$. NIV level in PP-treated silage stored at $37^{\circ} \mathrm{C}$ was higher compared with $20^{\circ} \mathrm{C}$ and $28^{\circ} \mathrm{C}(\mathrm{p}<$ 0.05 ), and its level in silage stored at $20^{\circ} \mathrm{C}$ was higher than $28^{\circ} \mathrm{C}$ $(\mathrm{p}<0.05)$. DON content in PP-treated silage conserved at $20^{\circ} \mathrm{C}$ was higher compared to CK and LP $(\mathrm{p}<0.05)$, and its content in LP-treated silage conserved at $28^{\circ} \mathrm{C}$ was higher in comparison with $\mathrm{CK}$ and $\mathrm{PP}(\mathrm{p}<0.05)$. At $37^{\circ} \mathrm{C}, \mathrm{DON}$ level in silage treated with LP was higher than CK and $\mathrm{PP}(\mathrm{p}<0.05)$, and its level in silage treated with $\mathrm{CK}$ was lower compared with $\mathrm{PP}$ $(\mathrm{p}<0.05)$. With no additive, silage conserved at $20^{\circ} \mathrm{C}$ had a higher value of DON in contrast with $28^{\circ} \mathrm{C}$ and $37^{\circ} \mathrm{C}(\mathrm{p}<0.05)$. DON value in silage treated with LP increased significantly from 76.2 to $179 \mathrm{ng} / \mathrm{g}$ as storage temperature increased from $20^{\circ} \mathrm{C}$ to $37^{\circ} \mathrm{C}$. With the application of PP, DON level in silage ensiled at $20^{\circ} \mathrm{C}$ was much higher compared to $28^{\circ} \mathrm{C}$ and $37^{\circ} \mathrm{C}(\mathrm{p}<0.05)$, and its level in silage ensiled at $28^{\circ} \mathrm{C}$ was lower than $37^{\circ} \mathrm{C}(\mathrm{p}<0.05)$. At $20^{\circ} \mathrm{C}$, the 3 -ADON level in silage treated with CK was higher in comparison with LP and PP $(\mathrm{p}<0.05)$, whereas there were no differences on $3-A D O N$ level for all the remaining comparisons ( $\mathrm{p}>0.05)$. PP-treated silage stored at $20^{\circ} \mathrm{C}$ had a higher level of T-2 compared to CK and $\mathrm{LP}(\mathrm{p}<0.05)$. OTA value in PP-treated silage ensiled at $28^{\circ} \mathrm{C}$ was higher compared with CK and LP $(\mathrm{p}<0.05)$. When storage temperature increased to $37^{\circ} \mathrm{C}$, silage treated with $\mathrm{CK}$ had a higher content of OTA in contrast with LP and PP $(p<0.05)$, and LP-treated silage had a lower content of OTA than PP $(\mathrm{p}<0.05)$. Without any additive, OTA level in silage ensiled at $37^{\circ} \mathrm{C}$ was higher compared to $20^{\circ} \mathrm{C}$ and $28^{\circ} \mathrm{C}(\mathrm{p}<0.05)$. OTA level in PP-treated silage ensiled at $37^{\circ} \mathrm{C}$ was higher in comparison with $20^{\circ} \mathrm{C}$ and $28^{\circ} \mathrm{C}(\mathrm{p}<0.05)$, and its level in PPtreated silage ensiled at $20^{\circ} \mathrm{C}$ was lower than $28^{\circ} \mathrm{C}(\mathrm{p}<0.05)$. ZEA content in PP-treated silage conserved at $20^{\circ} \mathrm{C}$ and $28^{\circ} \mathrm{C}$ was higher compared with CK and LP $(p<0.05)$. The utilization of LP led to a higher value of ZEA in silage conserved at $37^{\circ} \mathrm{C}$ in comparison with $28^{\circ} \mathrm{C}(\mathrm{p}<0.05)$, whereas $\mathrm{ZEA}$ value in PP-treated silage conserved at $28^{\circ} \mathrm{C}$ was higher than $20^{\circ} \mathrm{C}$ and $37^{\circ} \mathrm{C}(\mathrm{p}<0.05)$.

\section{DISCUSSION}

In the present experiment (Table 5), LP-treated corn silage stored at any temperature had a lower level of NH3-N and a higher number of yeast in comparison with $\mathrm{CK}$, which is in agreement with Filya et al [20]. Without any additive, LAB number in corn silage stored at $37^{\circ} \mathrm{C}$ was lower than $20^{\circ} \mathrm{C}$ and $28^{\circ} \mathrm{C}$, and a study found the similar phenomenon [21]. According to Table 6, the application of LP resulted in a higher content of WSC in corn silage stored at any temperature compared to $\mathrm{CK}$, it was reported that its concentration in corn silage treated with LP was lower than CK [20]. EE content decreased from $2.69 \%$ in corn to $2.09 \%$ to $2.29 \%$ of corn silage, perhaps microbial activity during fermentation degraded some EE. Nitrate level in corn was $383 \mathrm{mg} / \mathrm{kg}$, and decreased to 61.1 to $91.4 \mathrm{mg} / \mathrm{kg}$ after ensiling. Both corn and silage were safe in terms of nitrate content, because their concentrations were below the limit level $(1,000 \mathrm{mg} / \mathrm{kg})$. A study showed that nitrate contents in corn were 374 and $433 \mathrm{mg} / \mathrm{kg}$, and reduced to 18.5 to $111 \mathrm{mg} / \mathrm{kg}$ of corn silages [22].

The eight mycotoxins in this experiment can be divided into Aspergillus and Fusarium toxins, with $\mathrm{AFB}_{1}$ and OTA belonging to Aspergillus toxins, and Fusarium toxins consisting of the remaining six toxins. As can be seen from Table 4 and $7, \mathrm{AFB}_{1}$ existed in pre- and post-fermented corn samples, and its content was higher in corn $(30.2 \mathrm{ng} / \mathrm{g})$ compared with corn silage (23.4 to $24.5 \mathrm{ng} / \mathrm{g}$ ). This result indicated that $\mathrm{AFB}_{1}$ had a slow degradation during fermentation, and agrees with Kalac and Woodford [23]. However, $\mathrm{AFB}_{1}$ level was higher in corn silage when compared with pre-fermented samples [24], suggesting that $A$. flavus and A. parasiticus activity was enhanced during storage. Silage contamination with $\mathrm{AFB}_{1}$ was also found in Argentina [25], Egypt [26] and France [27]. These phenomena above show that $\mathrm{AFB}_{1}$ infection may be influenced by field environment where forage crop grow, and is usually concerned with tropical or subtropical regions with a higher temperature. Treatment and storage temperature did not have an effect on $\mathrm{AFB}_{1}$ level in corn silage at this experiment, however. OTA is a common contaminant of corn in temperate regions, and its level in corn was $34.4 \mathrm{ng} / \mathrm{g}$ at this experiment. Conservation temperature has a significant effect on OTA content in corn silage, and the application of LP and PP decreased its level in corn silage stored at $37^{\circ} \mathrm{C}$ compared to $\mathrm{CK}$.

Most information for Fusarium toxins is for DON in corn silage. DON content in CK-treated corn silage stored at any temperature was lower than that of corn (Tables 4,7), and two workers found a significant decrease in DON content after ensiling [28], perhaps because Fusarium species belong to field molds and their activity was suppressed by low oxygen and $\mathrm{pH}$ environment of silage [29]. In this experiment, storage temperature had a remarkable effect on DON level, and its level was not reduced in corn silage treated with LP and PP, whereas one study demonstrated that storage temperature did not affect DON stability [28]. Furthermore, their results showed that ensiling with low DM and prolonging storage time led to mycotoxin degradation of corn silage. DON level was also influenced by silage distribution in a silo, proved by two studies. One study showed that a higher content of DON was detected on the top of corn silage [27], and a lower concentration of it was found at the bottom of corn silage by the same workers [27]. On the whole, ZEA level kept unchanged in corn silage in this study, and this result was in accordance with Gonzales Pereyra et al [25]. 


\section{CONFLICT OF INTEREST}

We certify that there is no conflict of interest with any financial organization regarding the material discussed in the manuscript.

\section{ACKNOWLEDGMENTS}

This work was supported by China Forage and Grass Research System (CARS-35), Agro-scientific Research in the Public Interest (201303061), Project on achievements transformation and extension of Tianjin agricultural science and technology (201404040), Project on science and technology plan of Inner Mongolia and Project on test demonstration and service support of agricultural technology (Popularizing demonstration and application of whole-plant corn silage). The authors thank David B. Hannaway from Oregon State University for assistance of words review. Thanks also go to Heather HallenAdams from University of Nebraska due to her comments and suggestions on mycotoxin degradation.

\section{REFERENCES}

1. Reddy KRN, Salleh B, Saad B, et al. An overview of mycotoxin contamination in foods and its implications for human health. Toxin Rev 2010;29:3-26.

2. Tsiplakou E, Anagnostopoulos C, Liapis K, Haroutounian SA, Zervas G. Determination of mycotoxins in feedstuffs and ruminant's milk using an easy and simple LC-MS/MS multiresidue method. Talanta 2014;130:8-19.

3. Riley RT. Chapter 7 Mechanistic interactions of mycotoxins: theoretical considerations. Mycotoxins in agriculture and food safety. New York, USA: Marcel Dekker Inc; 1998.

4. Scott PM. Industrial and farm detoxification processes for mycotoxins. Rev Med Vet 1998;149:543-8.

5. Alonso VA, Pereyra CM, Keller LAM, et al. Fungi and mycotoxins in silage: an overview. J Appl Microbiol 2013;115:63743.

6. Huwig A, Freimund S, Kappeli O, Dutler H. Mycotoxin detoxication of animal feed by different adsorbents. Toxicol Lett 2001;122:179-88.

7. Guerre P. Interest of the treatments of raw materials and usage of adsorbents to decontaminate animal food containing mycotoxins. Rev Med Vet 2000;151:1095-106.

8. Cheli F, Campagnoli A, Dell' Orto V. Fungal populations and mycotoxins in silages: From occurrence to analysis. Anim Feed Sci Technol 2013;183:1-16.

9. Kollarczik B, Gareis M, Hanelt M. In vitro transformation of the Fusarium mycotoxins deoxynivalenol and zearalenone by the normal gut microflora of pigs. Nat Toxins 1994;2:105-10.

10.Storm IDM, Sørensen JL, Rasmussen RR, Nielsen KF, Thrane U. Mycotoxins in silage. Stewart Postharvest Rev 2008;4:1-12.
11.Niderkorn V, Boudra H, Morgavi DP. Binding of Fusarium mycotoxins by fermentative bacteria in vitro. J Appl Microbiol 2006;101:849-56.

12. Damoglou AP, Shannon W, Downey GA. The interaction between Fusarium and their mycotoxins in grass silage. J Sci Food Agric 1984;35:279-84.

13. Niderkorn V, Morgavi DP, Pujos E, Tissandier A, Boudra H. Screening of fermentative bacteria for their ability to bind and biotransform deoxynivalenol, zearalenone and fumonisins in an in vitro simulated corn silage model. Food Addit Contam 2007;24:406-15.

14. Reyneri A. The role of climatic condition on mycotoxin production in cereal. Vet Res Commun 2006;30(Suppl 1):87-92.

15. Sweeney MJ, Dobson ADW. Mycotoxin production by Aspergillus, Fusarium and Penicillium species. Int J Food Microbiol 1998;43:141-58.

16.Zhang Q, Li XJ, Zhao MM, Yu Z. Lactic acid bacteria strains for enhancing the fermentation quality and aerobic stability of Leymus chinensis silage. Grass Forage Sci 2016;71:472-81.

17. Van Soest PJ, Robertson PJ, Lewis BA. Methods for dietary fiber, neutral detergent fiber, and nonstarch polysaccharides in relation to animal nutrition. J Dairy Sci 1991;74:3583-97.

18. Anastassiades M, Lehotay SJ, Stajnbaher D, Schenck FJ. Fast and easy multiresidue method employing acetonitrile extraction/partitioning and "dispersive solid-phase extraction" for the determination of pesticide residues in produce. J AOAC Int 2003;86:412-31.

19. Yogendrarajah P, Poucke CV, Meulenaer BD, Saeger SD. Development and validation of a QuEChERS based liquid chromatography tandem mass spectrometry method for the determination of multiple mycotoxins in spices. J Chromatogr A 2013;1297:1-11.

20. Filya I, Sucu E, Karabulut A. The effect of Lactobacillus buchneri on the fermentation, aerobic stability and ruminal degradability of maize silage. J Appl Microbiol 2006;101:1216-23.

21. Wang C, Nishino N. Effects of storage temperature and ensiling period on fermentation products, aerobic stability and microbial communities of total mixed ration silage. J Appl Microbiol 2013;114:1687-95.

22. Borreani G, Tabacco E. Bio-based biodegradable film to replace the standard polyethylene cover for silage conservation. J Dairy Sci 2015;98:386-94.

23. Kalac P, Woodford MK. A review of some aspects of possible associations between the feedings of silage and animal health. Br Vet J 1982;138:305-20.

24. Keller LAM, Keller KM, Monge MP, et al. Gliotoxin contamination in pre- and postfermented corn, sorghum and wet brewer's grains silage in Sao Paulo and Rio de Janeiro State, Brazil. J Appl Microbiol 2012;112:865-73.

25. Gonzales Pereyra ML, Alonso VA, Sager R, et al. Fungi and selected mycotoxins in pre- and postfermented corn silage. J Appl Microbiol 2008;104:1034-41. 
26.El-Shanawany AA, Mostafa ME, Barakat A. Fungal population and mycotoxins in silage in Assiut and Sohag governorates in Egypt, with a special reference to characteristic Aspergilli toxins. Mycopathologia 2005;159:281-9.

27. Richard E, Heutte N, Bouchart V, Garon D. Evaluation of fungal contamination and mycotoxin production in maize silage. Anim Feed Sci Technol 2009;148:309-20.
28. Boudra H, Morgavi DP. Reduction in Fusarium toxin levels in corn silage with low dry matter and storage time. J Agric Food Chem 2008;56:4523-8.

29. Fink-Gremmels J. Mycotoxins in forages. In: Diaz DE, editor. The mycotoxin blue book. Nottingham, UK: Nottingham University Press; 2005. pp. 249-68. 